\title{
Cold tolerance of forage plant species
}

\section{Tolerância ao frio em espécies de forrageiras}

\author{
João Manetti Filho ${ }^{1}$; Carolina Maria Gaspar de Oliveira ${ }^{2 *}$; \\ Paulo Henrique Caramori²; Getulio Takashi Nagashima²; \\ Fernando Braz Tangerino Hernandez ${ }^{3}$
}

\begin{abstract}
The occurrence of frost in southern and southeastern Brazil affects pasture quality and limits the use of forage species with high yield potential. Therefore, elucidating the cold tolerance of individual forage species could facilitate the selection of species that will optimize production and animal feeding throughout the year. Accordingly, the aim of the present study was to evaluate the cold tolerance of forage species to low temperatures, based on cell membrane stability and photoinhibition. Alfalfa (Medicago sativa), sorghum (Sorghum bicolor), black oat (Avena strigosa), marandu grass (Urochloa brizantha), pearl millet (Pennisetum americanum), mombaça grass (Megathyrsus maximus), and bermuda grass 'Tifton 85' (Cynodon spp) plants were subjected to temperatures of $0.2,-0.9,-1.8,-2.7,-4.1,-4.6$, and $-6.2{ }^{\circ} \mathrm{C}$ for $1 \mathrm{~h}$ in a growth chamber. Cell membrane stability and photoinhibition were based on the electrical conductivity of leaf section solutions and chlorophyll fluorescence, respectively. Initial cold damage corresponded to a sudden increase in leaf solution conductivity and decrease in fluorescence. Millet and sorghum were able to tolerate exposure to temperatures as low as $-2.7^{\circ} \mathrm{C}$, whereas black oat, marandu grass, alfafa, and mombaça grass were able to tolerate exposure to $-4.1{ }^{\circ} \mathrm{C}$, and bermuda grass

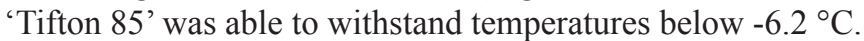

Key words: Frost. Fluorescence. Ion lixiviation. Conductivity test. Low temperature.

\section{Resumo}

A ocorrência de geadas no Sudeste e Sul do Brasil afeta a qualidade das pastagens e limita o uso de espécies com elevado potencial produtivo. O conhecimento da tolerância das forrageiras ao estresse por baixa temperatura contribui para a seleção das melhores espécies a serem utilizadas, levando à otimização de sua produção e garantindo o pastejo dos animais o ano inteiro. Assim, o objetivo deste trabalho foi avaliar a tolerância de espécies forrageiras às temperaturas baixas pela estabilidade da membrana celular e fotoinibição após o estresse por frio. Foram analisadas as forrageiras: alfafa (Medicago sativa), sorgo (Sorghum bicolor), aveia-preta (Avena strigosa), capim-marandu (Urochloa brizantha), milheto (Pennisetum americanum), capim-mombaça (Megathyrsus maximus) e Tifton 85 (Cynodon spp). As plantas foram submetidas às temperaturas de 0,$2 ;-0,9 ;-1,8 ;-2,7 ;-4,1 ;-4,6 \mathrm{e}-6,2^{\circ} \mathrm{C}$, durante uma hora, no interior de câmara de crescimento com condições de luminosidade e temperatura controladas, e avaliadas por meio do teste de condutividade elétrica da solução de secções foliares e fluorescência. O início dos danos correspondeu a um aumento súbito na condutividade elétrica da solução e diminuição na fluorescência. A tolerância das espécies forrageiras ao frio foi até a temperatura

1 Discente, Curso de Doutorado, Programa de Pós-Graduação em Agronomia, Universidade Estadual Paulista, UNESP, Campus Ilha Solteira, Ilha Solteira, SP, Brasil. E-mail: j.manetti.filho@uol.com.br

2 Pesquisadores, Instituto Agronômico do Paraná, IAPAR, Londrina, PR, Brasil. E-mail: carolina@iapar.br; pcaramori@gmail. com; gtnagashima@iapar.br

3 Prof., UNESP, Campus Ilha Solteira, Ilha Solteira, SP, Brasil. E-mail: fbthtang@agr.feis.unesp.br

* Author for correspondence 
$-2,7^{\circ} \mathrm{C}$ para milheto e sorgo $-4,1^{\circ} \mathrm{C}$ para alfafa, aveia-preta, Marandu e Mombaça, e inferior a $-6,2^{\circ} \mathrm{C}$ para o Tifton 85 .

Palavras-chave: Geada. Fluorescência. Lixiviação de íons. Condutividade elétrica. Temperatura baixa.

\section{Introduction}

Pastures are the main source of livestock feed in Brazil, owing to their low cost, when compared to other sources of nutrition. However, the productivity of such pastures is generally low, partly because little is known about the behavior of forage plants under different environmental conditions (MOREIRA et al., 2015). In many parts of southern Brazil, the climatic conditions of the cold season are severe enough to constrain animal production, since frosts interrupt the growth of forage plants (CANTO et al., 2010). Therefore, the selection of species that are tolerant to regional frost severity would improve the planning of animal feeding and, thereby, reduce the seasonality of feed production, and to achieve this, it is necessary to understand the cold tolerance of each species and cultivar (COSTA et al., 2008).

When plants are subject to stress, the stability of the whole organism is disrupted, including the alteration of metabolic routes and production of excess electrons, which increase intracellular levels of reactive oxygen species (ROS) that can damage cell structures. As part of the process, the plasma membrane is one of the first cellular structures to be affected by ROS, which destroy the lipid layer and impair its ability to interact with the cell's external environment (GILL; TUTEJA, 2010). This loss of membrane integrity includes the increase of membrane permeability and subsequent leaching of electrolytes, which reduces photosynthesis and mitochondrial activity (LIN et al., 1985). Therefore, evaluating plasma membranes can provide insight into overall plant health.

Among the tests used to evaluate membrane degradation, measuring electrical conductivity is relatively quick, cheap, and suitable for the analysis of large numbers of samples. This technique is also considered very versatile and highly sensitive for evaluating the tolerance of plants to stress (ARVIN; DONNELLY, 2008; MOSHTAGHI et al., 2009). Electrical conductivity has been used to quantify cell membrane damage after exposure to a variety of abiotic stressors, including cold, and has been used in a variety of crop species, including alfalfa Medicago sativa L. (SULC et al., 1991), olive - Olea europaea L. (BARRANCO et al., 2005), potato - Solanum tuberosum L.(ARVIN; DONNELLY, 2008), wheat - Triticum aestivum L (HABIBI et al., 2011), and various eucalyptus species - Eucalyptus spp. (FLORIANI et al., 2013).

Low temperature stress can also affect photosynthesis by reducing the export of photosynthates from the chloroplasts (KRATSCH; WISE, 2000). The process has even been reported to occur in certain cold-sensitive plants, mainly owing to the alteration or reorganization of thylakoid components, such as the loss of membrane polyps (BERTAMINI et al., 2007), which reduces electron transport and phosphorylation (RAPACZ, 2007).

Meanwhile, chlorophyll fluorescence provides insight into the state and energy use of photosystem 2 - PSII (MAXWELL; JOHNSON, 2000). Chlorophyll fluorescence has been used to evaluate the effect of environmental factors on photosynthetic metabolism and to measure plant stress tolerance (PERBONI et al., 2015). Several studies have shown that cold stress reduces the ratio variable fluorescence to maximum fluorescence ( $\mathrm{Fv} / \mathrm{Fm})$, which indicates that PSII is sensitive to low temperatures (JATIMLIANSKY et al., 2004; RAPACZ, 2007; PERBONI et al., 2015), since Fv/ $\mathrm{Fm}$ ratio is an indicator of the energy efficiency of the PSII reaction center (PAPAGEORGIOU; GOVINDJEE, 2011). The typical Fv/Fm values of unstressed plants range from 0.75 to 0.85 , and lower values are generally observed when plants are 
exposed to stress (BOLHÀR-NORDENKAMPF; ÖQUIST, 1993; KALAJI; GUO, 2008).

The objective of the present study was to evaluate the cold tolerance of forage plant species by assessing the effects of low temperature on cell membrane stability and photoinhibition.

\section{Material and Methods}

The experiment was conducted at Instituto Agronômico do Paraná (IAPAR) experimental station in Londrina, Paraná, Brazil, and included black oat (Avena strigosa), marandu grass (Urochloa brizantha), bermuda grass 'Tifton 85' (Cynodon sp.), alfafa (Medicago sativa), mombaça grass (Megathyrsus maximus), millet (Pennisetum americanum), and sorghum (Sorghum bicolor). A completely randomized experimental design was used, with six replicates per forage species. Bermuda grass 'Tifton 85' was propagated from $\sim 20$-cm branches, whereas the other species were propagated by sowing seeds in $1000-\mathrm{mL}$ pots that contained a 2:1 mixture of soil and manure, as well as $1 \mathrm{~kg} 4-30-10\left(\mathrm{~N}-\mathrm{P}_{2} \mathrm{O}_{5}-\mathrm{K}_{2} \mathrm{O}\right)$ fertilizer per $\mathrm{m}^{3}$.

The plants were grown in a greenhouse for two months and then exposed to low temperatures inside a growth chamber (S. S. Cientific, LondrinaPR) that was programmed to reach minimum temperatures of $0.2,-0.9,-1.8,-2.7,-4.1,-4.6$, or $-6.2{ }^{\circ} \mathrm{C}$ for one hour before returning to ambient temperature (Figure 1).

Figure 1. Temperature curves of cold-temperature treatments used in the present study (the sudden increases and decreases correspond to the times when the chamber's cooling system automatically switched on and off, respectively, throughout each treatment).

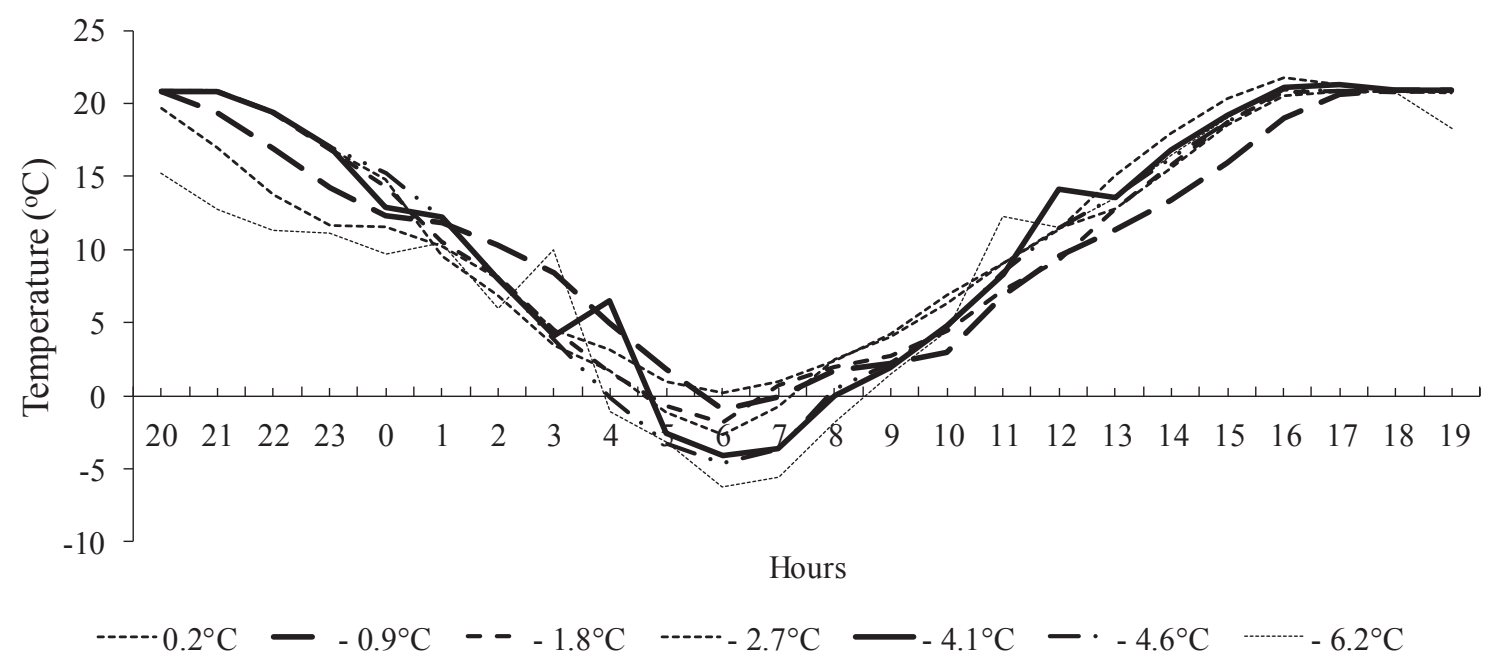

Chlorophyll fluorescence and the electrical conductivity of leaf sections solutions were performed before and after treatment, in order to assess the damage caused by low-temperature exposure.

Chlorophyll fluorescence was measured using a Multi-mode Chlorophyll Fluorometer (Optiscience model OS5). Duplicate readings were obtained from the adaxial epidermis of the same fully expanded leaf, before and after cold stress, and mean initial fluorescence (Fo), maximum fluorescence (Fm), variable fluorescence $(\mathrm{Fv})$, and quantum efficiency of PS II - Fv/Fm (BOLHÀR-NORDENKAMPF; ÖQUIST, 1993) values were calculated. 
Electrical conductivity, which is used to measure the degree of cell membrane damage caused by stress, is based on the leaching of leaf cell electrolytes (ARVIN; DONNELLY, 2008). Before and after low-temperature exposure, leaves from each plant were cut into pieces $\left(\sim 1 \mathrm{~cm}^{2}\right)$, and 10 sections from each plant were immersed in $20 \mathrm{ml}$ deionized water. After $24 \mathrm{~h}$ at $25^{\circ} \mathrm{C}$, the electrical conductivity $(\mu \mathrm{S}$ $\mathrm{cm}^{-1}$ ) of the solutions was measured.

Analysis of variance was used to assess the effects of the cold-stress treatments, and when significant differences were detected, Tukey's test
$(\mathrm{P} \leq 0.05)$ was used to compare means.

\section{Results and Discussion}

Cold treatment affected the chlorophyll fluorescence of each species, except for bermuda grass 'Tifton 85' (Table 1). According to BolhàrNordenkampf and Öquist (1993) and Kalaji and Guo (2008), the typical value of the quantum efficiency $(\mathrm{Fv} / \mathrm{Fm})$ of a plant without stress ranges from 0.75 to 0.85 , so values lower than 0.70 were considered to indicate damage to photosystem II (PSII).

Table 1. Maximum photochemical efficiency of photosystem II (Fv/Fm - Variable fluorescence/Maximum fluorescence) of forage plants exposed to cold stress.

\begin{tabular}{cccccccc}
\hline Temperature & \multicolumn{7}{c}{ Forage species } \\
\hline$\left({ }^{\circ} \mathrm{C}\right)$ & Alfalfa & Black oat & Marandu & Pear millet & Mombaça & Sorghum & 'Tifton 85' \\
\hline Initial & $0.780 \mathrm{a}^{*}$ & $0.756 \mathrm{a}$ & $0.783 \mathrm{a}$ & $0.749 \mathrm{a}$ & $0.772 \mathrm{a}$ & $0.742 \mathrm{a}$ & $0.750 \mathrm{a}$ \\
0.2 & $0.799 \mathrm{a}$ & $0.758 \mathrm{a}$ & $0.732 \mathrm{a}$ & $0.750 \mathrm{a}$ & $0.763 \mathrm{a}$ & $0.738 \mathrm{a}$ & $0.754 \mathrm{a}$ \\
-0.9 & $0.778 \mathrm{a}$ & $0.755 \mathrm{a}$ & $0.784 \mathrm{a}$ & $0.742 \mathrm{a}$ & $0.764 \mathrm{a}$ & $0.746 \mathrm{a}$ & $0.734 \mathrm{a}$ \\
-1.8 & $0.767 \mathrm{a}$ & $0.761 \mathrm{a}$ & $0.778 \mathrm{a}$ & $0.741 \mathrm{a}$ & $0.772 \mathrm{a}$ & $0.747 \mathrm{a}$ & $0.748 \mathrm{a}$ \\
-2.7 & $0.752 \mathrm{a}$ & $0.741 \mathrm{a}$ & $0.759 \mathrm{a}$ & $0.612 \mathrm{ab}$ & $0.721 \mathrm{a}$ & $0.690 \mathrm{a}$ & $0.729 \mathrm{a}$ \\
-4.1 & $0.677 \mathrm{a}$ & $0.477 \mathrm{ab}$ & $0.560 \mathrm{a}$ & $0.404 \mathrm{~b}$ & $0.553 \mathrm{ab}$ & $0.371 \mathrm{~b}$ & $0.734 \mathrm{a}$ \\
-4.6 & $0.618 \mathrm{a}$ & $0.598 \mathrm{a}$ & $0.587 \mathrm{a}$ & $0.155 \mathrm{c}$ & $0.338 \mathrm{bc}$ & $0.150 \mathrm{~b}$ & $0.734 \mathrm{a}$ \\
-6.2 & $0.024 \mathrm{~b}$ & $0.272 \mathrm{~b}$ & $0.194 \mathrm{~b}$ & $0.056 \mathrm{c}$ & $0.076 \mathrm{c}$ & $0.139 \mathrm{~b}$ & $0.696 \mathrm{a}$ \\
\hline CV\% & 18.3 & 25.0 & 25.2 & 22.4 & 26.4 & 24.3 & 5.6 \\
\hline LSD & 0.22 & 0.30 & 0.30 & 0.22 & 0.29 & 0.24 & 0.08 \\
\hline
\end{tabular}

*Different lowercase letters indicate that means within columns are significantly different, according to Tukey's test (P $\leq 0.05)$. CV $=$ Coefficient of variation. LSD $=$ Least Significant Difference.

Millet and sorghum first exhibited cold damage upon exposure to $-2.7{ }^{\circ} \mathrm{C}$, whereas black oat, marandu grass, alfafa, and mombaça grass first exhibited cold damage at $-4.1^{\circ} \mathrm{C}$, and bermuda grass 'Tifton 85 ' first exhibited cold damage at $-6.2^{\circ} \mathrm{C}$.

The reduction of chlorophyll fluorescence with decreasing minimum temperature indicates that the plants were affected by the cold because of damage to photosystems I and II, that (BERTAMINI et al., 2007; EQUIZA; FRANCKO, 2010). Thus, even if $\mathrm{Fv} / \mathrm{Fm}$ is only reduced slightly, the photosynthetic electron transport of cold-sensitive plants can be inhibited (HENDRICKSON et al., 2004).

Using an approach that was similar to that of the present study, Bertamini et al. (2007) found that cold exposure reduced the $\mathrm{Fv} / \mathrm{Fm}$ of coldsensitive grapevine cultivars but did not affect that of more tolerant cultivars, thereby indicating that an important part of the PSII reaction center was damaged by cold exposure.

Zulini et al. (2010) concluded that the Fv/Fm ratio was a good criterion for identifying the beginning of 
damage in 'Pinot noir' buds and proposed a critical value of 0.40 . Reductions in PSII activity have also been reported for cold-stressed wheat - Triticum aestivum L. (BRESTIC et al., 2012), Guatemalan grass - Tripsacum dactyloides (JATIMLIANSKY et al., 2004), and young jatropha plants - Jatropha curcas (PLOSCHUK et al., 2014). Rapacz (2007) also reported that the measurement of chlorophyll a fluorescence was a rapid and objective method for evaluating cold damage in wheat plants.

Cold treatment affected the electrical conductivity of each species, except for bermuda grass 'Tifton 85', which maintained similar values in all situations (Table 2). Therefore, low temperature did not damage the cell membranes of the bermuda grass 'Tifton 85 ', as previously reported for wheat 'Gaskoghen' (HABIBI et al., 2011) and olive 'Delghan' (MOSHTAGHI et al., 2009).

Table 2. Electrical conductivity $\left(\mu \mathrm{S} \mathrm{cm}^{-1}\right)$ of leaf-section solutions from forage plants exposed to cold stress.

\begin{tabular}{cccccccc}
\hline Temperature & \multicolumn{7}{c}{ Forage species } \\
\hline$\left({ }^{\circ} \mathrm{C}\right)$ & Alfalfa & Black oat & Marandu & Pearl millet & Mombaça & Sorghum & 'Tifton $85^{\prime}$ \\
\hline Initial & $6.44 \mathrm{~b} *$ & $6.24 \mathrm{~b}$ & $24.08 \mathrm{c}$ & $25.11 \mathrm{c}$ & $12.30 \mathrm{~b}$ & $46.46 \mathrm{~b}$ & $7.41 \mathrm{a}$ \\
0.2 & $13.23 \mathrm{~b}$ & $7.84 \mathrm{~b}$ & $32.97 \mathrm{bc}$ & $12.86 \mathrm{c}$ & $14.77 \mathrm{~b}$ & $23.44 \mathrm{~b}$ & $5.88 \mathrm{a}$ \\
-0.9 & $4.57 \mathrm{~b}$ & $11.59 \mathrm{~b}$ & $34.29 \mathrm{bc}$ & $18.35 \mathrm{c}$ & $19.38 \mathrm{~b}$ & $35.68 \mathrm{~b}$ & $5.79 \mathrm{a}$ \\
-1.8 & $3.67 \mathrm{~b}$ & $7.27 \mathrm{~b}$ & $25.34 \mathrm{c}$ & $29.46 \mathrm{c}$ & $12.22 \mathrm{~b}$ & $34.67 \mathrm{~b}$ & $4.96 \mathrm{a}$ \\
-2.7 & $12.63 \mathrm{~b}$ & $7.03 \mathrm{~b}$ & $73.71 \mathrm{bc}$ & $126.51 \mathrm{bc}$ & $21.18 \mathrm{~b}$ & $75.74 \mathrm{~b}$ & $4.74 \mathrm{a}$ \\
-4.1 & $37.76 \mathrm{ab}$ & $102.50 \mathrm{a}$ & $149.60 \mathrm{~b}$ & $75.37 \mathrm{bc}$ & $57.20 \mathrm{~b}$ & $266.38 \mathrm{a}$ & $5.59 \mathrm{a}$ \\
-4.6 & $34.10 \mathrm{ab}$ & $44.14 \mathrm{ab}$ & $137.41 \mathrm{bc}$ & $200.31 \mathrm{ab}$ & $80.62 \mathrm{~b}$ & $291.03 \mathrm{a}$ & $7.98 \mathrm{a}$ \\
-6.2 & $55.68 \mathrm{a}$ & $92.03 \mathrm{a}$ & $292.28 \mathrm{a}$ & $270.58 \mathrm{a}$ & $329.58 \mathrm{a}$ & $290.40 \mathrm{a}$ & $6.76 \mathrm{a}$ \\
\hline CV\% & 106.4 & 98.69 & 67.44 & 79.03 & 80.91 & 55.06 & 42.8 \\
\hline LSD & 41.28 & 63.45 & 96.21 & 138.32 & 102.16 & 135.15 & 4.85 \\
\hline
\end{tabular}

*Different lowercase letters indicate that means within columns are significantly different, according to Tukey’s test $(\mathrm{P} \leq 0.05)$. CV $=$ Coefficient of variation. LSD $=$ Least Significant Difference.

The electric conductivity of pearl millet, marandu grass, and sorghum increased at $-2.7^{\circ} \mathrm{C}$, whereas the electrical conductivity of the other species, except for bermuda grass 'Tifton 85 ', increased at $-4.1^{\circ} \mathrm{C}$. Therefore, cold stress damaged the cell membranes of the cold-sensitive species and, thereby, caused electrolyte leaching (JATIMLIANSKY et al., 2004). According to Hasanuzzaman et al. (2013), this occurs because low temperatures cause fatty acids to become unsaturated and, thereby, alter the structure and fluidity of the membrane layer of lipids and proteins.

Similar stress-induced increases in electrolyte leaching have also been reported to occur in grapevine (BERTAMINI et al., 2007), wheat (HABIBI et al., 2011), maize, and Guatemala grass

\section{(JATIMLIANSKY et al., 2004).}

However, Jatimliansky et al. (2004) reported that the measurement of electrical conductivity was insufficiently sensitive for detecting differences in the cold tolerance of maize (Zea mays) genotypes. This was also observed for mombaça grass in the present study, where electrical conductivity only indicated damage at $-6.2{ }^{\circ} \mathrm{C}$, even though fluorescence measurement indicated that PSII was already affected at $-4.1{ }^{\circ} \mathrm{C}$. For the other species used in the present study, electrical conductivity was sufficiently sensitive, as reported for Medicago truncatula (THAPA et al., 2008).

The results of the present study demonstrate that it is possible to verify the cold tolerance of forage 
plants based on their responses to cold exposure in controlled environments. The consistency of the results is due to the homogeneity of temperature during cold exposure, as previously demonstrated in white clover - Trifolium repens (ANNICCHIARICO et al., 2001) and peanuts - Arachis hypogea (BRESOLIN et al., 2008).

\section{Conclusion}

Millet and sorghum were able to tolerate exposure to temperatures as low as $-2.7^{\circ} \mathrm{C}$, whereas black oat, marandu grass, alfafa, and mombaça grass were able to tolerate exposure to $-4.1{ }^{\circ} \mathrm{C}$, and bermuda grass 'Tifton $85^{\prime}$ ' was able to withstand temperatures below $-6.2^{\circ} \mathrm{C}$.

\section{References}

ANNICCHIARICO, P.; COLLINS, R. P.; FORNASIER, F.; RHODES, I. Variation in cold tolerance and spring growth among Italian white clover populations. Euphytica, Wageningen, v. 122, n. 2, p. 407-416, 2001.

ARVIN, M. J.; DONNELLY, D. J. Screening potato cultivars and wild species to abiotic stresses using an electrolyte leakage bioassay. Journal of Agricultural Science and Technology, Tehran, v. 10, n. 1, p. 33-42, 2008.

BARRANCO, D.; RUIZ, N.; GÓMEZ-DEL CAMPO, M. Frost tolerance of eight olive cultivars. HortScience, Baton Rouge, v. 40, n. 3, p. 558-560, 2005.

BERTAMINI, M.; ZULINI, L.; MUTHUCHELIAN, K.; NEDUNCHEZHIAN, N. Low night temperature effects on photosynthetic performance on two grapevine genotypes. Biologia Plantarum, Prague, v. 51, n. 2, p. 381-385, 2007.

BOLHÀR-NORDENKAMPF, H. R.; ÖQUIST, G. Chlorophyll fluorescence as a tool in photosynthesis research. In: HALL, D. O.; SCURLOCK, J. M. O.; BOLHÀR-NORDENKAMPF, H. R.; LEEGOOD, R. C.; LONG, S. P. (Ed.). Photosynthesis and production in a changing environment: a field and laboratory manual. London: Chapman \& Hall, 1993. p. 193-206.

BRESOLIN, A. P. S.; CASTRO, C. M.; HERTER, F. G.; OLIVEIRA, A. C.; FELIX, F. I.; CARVALHO, F.; PEREIRA, F. B.; VIEIRA, C. L.; FERREIRA, R.; BERTOLI, V. Tolerância ao frio do amendoim forrageiro.
Ciência Rural, Santa Maria, v. 38, n. 4, p. 1154-1157, 2008.

BRESTIC, M.; ZIVCAK, M.; KALAJI, H. M.; CARPENTIER, R.; ALLAKHVERDIEV, S. I. Photosystem II thermostability in situ: environmentally induced acclimation and genotype-specific reactions in Triticum aestivum L. Plant Physiology and Biochemistry, Bari, v. 57, n. 1, p. 93-105, 2012.

CANTO, M. W.; JOBIM, C. C.; PAGLIARINI, M. S.; PANCERA JÚNIOR, E. J.; BARTH, NETO, A.; INTROVINI, E. P.; ZANFOLIN, P. R. L.; FERREIRA, C. W.; MATIVI, T. M.; ALMEIDA, G. M.; VIZZOTTO, B. A pecuária de corte no Paraná - desenvolvimento, caracterização e o papel das pastagens. Scientia Agraria Paranaensis, Marechal Candido Rondon, v. 9, n. 3, p. 5-21, 2010.

COSTA, C.; MEIRELLES, P. R. L.; SILVA, J. J.; FACTORI, M. A. Alternativas para contornar a estacionalidade de produção de forragens. Veterinária e Zootecnia, Botucatu, v. 15, n. 2, p. 193-203, 2008.

EQUIZA, M. A.; FRANCKO, D. A. Assessment of freezing injury in palm species by chlorophyll fluorescence. HortScience, Baton Rouge, v. 45, n. 5, p. 845-848, 2010.

FLORIANI, M. M. P.; STEFFENS, C. A.; CHAVES, D. M.; AMARANTE, C. V. T.; PIKART, T. G.; RIBEIRO, M. T. Relação entre concentrações foliares de carboidratos solúveis totais e tolerância ao frio em diferentes espécies de Eucalyptus spp. Ciência Florestal, Santa Maria, v. 23, n. 1, p. 165-174, 2013.

GILL, S. S.; TUTEJA, N. Reactive oxygen species and antioxidant machinery in abiotic stress tolerance in crop plants. Plant Physiology and Biochemistry, Bari, v. 48, n. 12, p. 909-930, 2010.

HABIBI，F.; NORMAHAMADI， G. H.; HEIDARY SHARIF ABAD, H.; EIVAZI, A.; MAJIDI HERAVAN, E. Effect of cold stress on cell membrane stability, chlorophyll $\mathrm{a}$ and $\mathrm{b}$ contain and proline accumulation in wheat (Triticum aestivum L.) variety. African Journal of Agricultural Research, Lagos, v. 6, n. 27, p. 5854-5859, 2011.

HASANUZZAMAN, M.; NAHAR, K.; FUJITA, M. Extreme temperature responses, oxidative stress and antioxidant defense in plants. In: VAHDATI, K.; LESLIE, C. (Ed.). Abiotic stress - plant responses and applications in agriculture. Tehran: InTech, 2013. p. 169-205.

HENDRICKSON, L.; BALL, M. C.; WOOD, J. T.; CHOW, W. S.; FURBANK, R. T. Low temperature effects on photosynthesis and growth of grapevine. Plant, Cell \& Environment, Logan, v. 27, n. 7, p. 795-809, 2004. 
JATIMLIANSKY, J. R.; GARCÍA, M. D.; MOLINA, M. C. Response to chilling of Zea mays, Tripsacum dactyloides and their hybrid. Biologia Plantarum, Prague, v. 48, n. 4, p. 561-567, 2004.

KALAJI, M. H.; GUO, P. Chlorophyll fluorescence: a useful tool in barley plant breeding programs. In: SANCHEZ,A.; GUTIERREZ, S. J.(Ed.). Photochemistry research progress. New York: Nova Science Publishers Inc., 2008. p. 439-463.

KRATSCH, H. A.; WISE, R. R. The ultrastructure of chilling stress. Plant, Cell \& Environment, Logan, v. 23, n. 4, p. 337-350, 2000.

LIN, C. Y.; CHEN, Y. M.; KEY, J. L. Solute leakage in soybean seedlings under various heat shock regimes. Plant and Cell Physiology, Oxford, v. 26, n. 8, p. 14931498, 1985.

MAXWELL, K.; JOHNSON, G. N. Chlorophyll fluorescence a practical guide. Journal of Experimental Botany, Colchester, v. 51, n. 345, p. 659-668, 2000.

MOREIRA, A. L.; FAGUNDES, J. L.; YOSHIHARA, E.; BACKES, A. A.; BARBOSA, L. T.; OLIVEIRA JÚNIOR, L. F. G. de.; SANTOS, G. R. A.; SANTOS, M. A. S. A. Acúmulo de forragem em pastos de Tifton 85 adubados com nitrogênio e manejados sob lotação contínua. Semina: Ciências Agrárias, Londrina, v. 36, n. 3, p. 2275-2286, 2015. Suplemento 1.

MOSHTAGHI, E. A.; SHAHSAVAR, A. R.; TASLIMPOUR, M. R. Ionic leakage as indicators of cold hardiness in olive (Olea europaea L.). World Applied Sciences Journal, Babol, v. 7, n. 10, p. 1308-1310, 2009.
PAPAGEORGIOU, G. C.; GOVINDJEE. Photosystem II fluorescence: slow changes-scaling from the past. Journal of Photochemistry and Photobiology B: Biology, Quebec, v. 104, n. 1, p. 258-270, 2011.

PERBONI, A. T.; MARTINAZZO, E. G.; SILVA, D. M.; BACARIN, M. A Baixas temperaturas sobre a fluorescência da clorofila a em plantas de diferentes híbridos de canola. Ciência Rural, Santa Maria, v. 45, n. 2, p. 215-222, 2015.

PLOSCHUK, E. L.; BADOA, L. A.; SALINAS, M.; WASSNER, D. F.; WINDAUER, L. B.; INSAUSTI, P. Photosynthesis and fluorescence responses of Jatropha curcas to chilling and freezing stress during early vegetative stages. Environmental and Experimental Botany, Barcelona, v. 102, n. 1, p. 18-26, 2014

RAPACZ, M. Chlorophyll a fluorescence transient during freezing and recovery in winter wheat. Photosynthetica, Prague, v. 45, n. 3, p. 409-418, 2007.

SULC, R. M.; ALBRECHT, K. A.; DUKE, S. H. Leakage of intracellular substances as an indicator of freezing injury in alfalfa. Crop Science, Madison, v. 31, n. 2, p. 430-435, 1991.

THAPA, B.; ARORA, R.; KNAPP, A. D.; BRUMMER, E. C. Applying freezing test to quantify cold acclimation in Medicago truncatula. Journal of the American Society for Horticultural Science, Virginia, v. 133, n. 5, p. 684$691,2008$.

ZULINI, L. U. C. A.; FISCHER, C.; BERTAMINI, M. Chlorophyll fluorescence as a tool for evaluation of viability in freeze-stressed grapevine buds. Photosynthetica, Prague, v. 48, n. 2, p. 317-319, 2010. 
